\title{
HLA Genes and their Tremendous Polymorphism. Is It Clinically Relevant?
}

\author{
Ileana Constantinescu ${ }^{1,2 *}$ \\ ${ }^{1}$ Carol Davila" University of Medicine and Pharmacy, Romania \\ ${ }^{2}$ Centre for Immunogenetics and Virology, Fundeni Clinical Institute, Romania
}

*Corresponding author: Ileana Constantinescu, Centre for Immunogenetics and Virology, Fundeni Clinical Institute, Bucharest, Romania

\begin{tabular}{l}
\hline ARTICLE INFO \\
\hline Received: Meptember 02, 2019 \\
Published: 幽 September 11, 2019 \\
\hline Citation: Ileana Constantinescu. HLA \\
Genes and their Tremendous Polymor- \\
phism. Is It Clinically Relevant?. Biomed \\
J Sci \& Tech Res 21(2)-2019. BJSTR.
\end{tabular}

\section{ABSTRACT}

Abbreviations: MHC: Major Histocompatibility Complex; HLA: Human Leucocytes Antigens; SBT: Sequence-Based Typing; NGS: Next Generation Sequencing MS.ID.003579.

\section{Opinion}

Genetic polymorphisms and its clinical relevance are the hallmark of many research projects and clinical studies. The immune system is controlled and regulated by a cluster of genes - the human leucocytes antigens (HLA) genes which are very polymorphic. Therefore, the genetic variation of our immune response could generate different pathological situations in some specific diseases. The HLA genes, actually, the Major Histocompatibility Complex (MHC) includes the most diverse genes and their polymorphisms are involved in the outcome of transplantation, immune response in different types of cancer, viral infections, bacterial infections or parasitic infections and in autoimmune diseases. HLA genetic polymorphism had produced a lot of scientific debates in recent years. Our immune system is under pressure in order to respond to any external aggression from different forms of pathogens and also to (in) organ /cell transplantation. In the last situation HLA matching is crucial in order to have no immune response against the allograft. So, for HLA genes, polymorphism can occur preferentially in functional domains of a given molecule with important consequences on epitope selection and presentation [1,2]. In transplantation, HLA genes are identified for their polymorphisms in order to have the best perfect match between donor and recipient. Thus, by high resolution molecular typing -
PCR [3] and high throughput sequence-based typing (SBT) [4] also by next generation sequencing (NGS) [5] technology variants we can solve almost all HLA allele ambiguities with accuracy.

In the clinical practice there are three types of HLA allele ambiguities. Most common are multiple alleles that have the same nucleotide sequence in the region sequenced but differ in exons outside the sequenced region. These could be resolved by amplifying and sequencing the additional exons. HLA allele ambiguities due to cis/trans ambiguities, (e.g. HLA-B* 35:01:01 + *38:01:01 *53:01:01 $+* 39: 05)$. In this situation the HLA alleles share the same sequence motifs in different combinations. They could be solved by using additional group specific primers -GSPs or sequence specific primers -SSPs. Last, but not least, silent substitution are the third HLA allele ambiguities in which certain allele subtypes may differ at the nucleotide level but not in the expressed protein. Silent substitutions do not need to be resolved in many clinical transplant cases. On the other hand, it has been demonstrated by many researchers that at molecular levels, even one amino acid change in the sequence of HLA genes can cause dramatic alterations in the antigen binding affinity and consequently difference in efficiency of induction of $\mathrm{T}$ cell reactivity in vitro and in vivo $[2,6]$. 
The approach of HLA genes by NGS technologies in comparison to Sanger SBT enables massively parallel analysis, high throughput, and reduced cost. NGS exhibit better performance in terms of read length, accuracy and clinical applications requiring informatics infrastructure as well [5]. So, we can conclude that HLA gene polymorphisms can occur in functional regions of molecules, they have functional significance and, for sure, they have clinical relevance. Immune polymorphisms beyond classical MHC are expressed by MIC - A and MIC-B genes which are located next to HLA genes and are characterized by high diversity. Their tissue distribution is located on epithelial, endothelial cells and fibroblasts. It seems that MIC genes modulate the function of NK and CD8+ T cells by binding the NK G2D stimulating receptor [7]. MIC genes are also involved in transplant acute rejection as allo-antibodies against them that are often found in transplant recipients having complement mediated cytotoxicity against endothelial cells from the graft. In conclusion, high variability of immune-related genes is important to be highlighted into day to day clinical practice [8]. Through immune polymorphism we suggest a change in the approach of patients, by assessing personalized immunogenic profiling and then to look at other biological and clinical changes [8]. We believe that clinical aspects of many of our patients express, actually, genetic polymorphisms of their immune-related genes.

\section{ISSN: 2574-1241}

DOI: 10.26717/BJSTR.2019.21.003579

Ileana Constantinescu. Biomed J Sci \& Tech Res

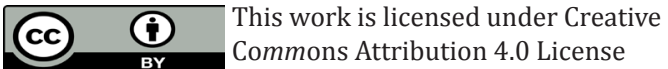

Submission Link: https://biomedres.us/submit-manuscript.php

\section{References}

1. Bjorkman PJ, Parham P (1990) Structure, function, and diversity of class I major histocompatibility complex molecules. Annu Rev Biochem 59: 253-288.

2. Bettinotti M, Kim CJ, Lee KH, Roden M, Cormier JN, et al. (1998) Stringent allele/epitope requirements for MART-1/Melan A immunodominance: implications for peptide-based immunotherapy. J Immunol 161(2): 877889.

3. Krausa P, Brywka M, Savage D, Hui KM, Bunce M, et al. (1995) Genetic polymorphism within HLA-A*02: significant allelic variation revealed in different populations. Tissue Antigens 45(4): 223-231.

4. Adams SD, Barracchini KC, Simonis TB, Stroncek D, Marincola FM (2001) High throughput HLA sequence-based typing utilizing the ABI prism 3700 analyzer. Tumori 87(2): s41-s44.

5. Liu L, Li Y, Li S, Hu N, He Y, et al. (2012) Comparison of Next-Generation Sequencing Systems. Journal of Biomedicine and Biotechnology Article ID 251364: 11.

6. Rivoltini L, Loftus DJ, Barracchini K, Arienti F, Mazzocchi A, et al. (1996) Binding and presentation of peptides derived from melanoma antigens MART- 1 and gp100 by HLA-A2 subtypes: implications for peptide-based immunotherapy. J Immunol 156(10): 3882-3891.

7. Cerwenka A, Lanier LL (2001) Ligands for natural killer cell receptors: redundancy or specificity. Immunol Rev 181(1): 158-169.

8. Rich RR, Fleisher AT, Shearer TW, Schroeder JR (2019) Clinical Immunology: Principles and Practice. In WH, Frew JA, Weyand MC (Eds.) ISBN-13 9780702068966, Elsevier 2019.

$\begin{array}{ll}\text { BIOMEDICAL } & \text { Assets of Publishing with us } \\ \text { RESEARCHES } & \text { - Global archiving of articles } \\ & \text { - Immediate, unrestricted online access } \\ & \text { - Rigorous Peer Review Process } \\ \end{array}$

